\title{
PRZEDSIĘBIORSTWA DZIALAJĄCE NA POLSKIM RYNKU OCHRONY ZDROWIA W ŚWIETLE TEORII KOSZTÓW TRANSAKCYJNYCH ${ }^{1}$
}

\section{Wstęp}

Teoria kosztów transakcyjnych w nurt teorii przedsiębiorstwa wpisuje się na gruncie nowej ekonomii instytucjonalnej. Artykuł ma na celu zwrócenie uwagi na praktyczne aspekty wykorzystania owej teorii, jak również na wskazanie możliwości dalszych kierunków badań w zakresie teorii kosztów transakcyjnych - w szczególności na rynku ochrony zdrowia. W opracowaniu podjęto próbę identyfikacji różnego rodzaju kosztów transakcyjnych na polskim rynku ochrony zdrowia. Ponadto zostały tu również omówione sposoby ewentualnej redukcji tych kosztów.

Teoria kosztów transakcyjnych stanowi trzon nowej ekonomii instytucjonalnej - dziedziny wciąż stosunkowo młodej w zakresie studiów akademickich, a przede wszystkim w odniesieniu do praktyki gospodarczej. W pierwszej części niniejszego opracowania zostaną ujęte podstawy teoretyczne dotyczące tejże teorii, natomiast $\mathrm{w}$ drugiej przytoczone praktyczne przykłady wykorzystania omawianych założeń teoretycznych.

\section{Nowa ekonomia instytucjonalna}

Nowa ekonomia instytucjonalna (NEI) zaliczana jest do tzw. alternatywnych teorii firmy. To właśnie na jej gruncie powstała teoria kosztów transakcyjnych, która stanowi główny przedmiot zainteresowania autora niniejszego opracowania. W ramach nowej ekonomii instytucjonalnej obok teorii kosztów transakcyjnych można wyróżnić również teorię agencji oraz teorię praw własności. Teorie te stanowią $\mathrm{w}$ dalszym ciągu stosunkowo nowy obszar dociekań badaczy akademickich, natomiast do praktyków gospodarczych prawie w ogóle

\footnotetext{
"Doktorant, asystent, Zakład Finansów Korporacji, Wydział Ekonomiczno-Socjologiczny UŁ.

${ }^{1}$ Publikacja współfinansowana ze środków Europejskiego Funduszu Społecznego w ramach Poddziałania 8.2.1. Programu Operacyjnego Kapitał Ludzki, w związku z realizacją Projektu „Doktoranci - Regionalna Inwestycja w Młodych naukowców społeczno-humanistycznych - Akronim D-RIM SH".
} 
jeszcze nie dotarły ${ }^{2}$. Do najbardziej rozpoznawalnych przedstawicieli tego nurtu ekonomii można zaliczyć znanych noblistów: Ronalda Coase'a, Douglasa North'a, Elinora Ostroma i Olivera Williamsona. Obok nich często wymieniany jest również Geoffrey Hodgson ${ }^{3}$.

Rozwój dziedziny, jaką jest nowa ekonomia instytucjonalna, jest odpowiedzią na narastające trudności, które towarzyszą wyjaśnianiu przez ekonomię neoklasyczną coraz liczniejszych zjawisk gospodarczych. Wzrastająca dynamika zmian gospodarczych oraz złożoność mechanizmów rozwoju sprawiają, że teorie neoklasyczne nie są w stanie nadążyć za tymi zmianami ${ }^{4}$. Niezdolność do odpowiedzi na tak ważne pytania, jak np. o to, jaka jest optymalna wielkość firmy, dlaczego powstają i upadają określone systemy gospodarcze czy też dlaczego rynek i państwo funkcjonują jako alternatywne mechanizmy koordynacji gospodarczej, doprowadziła do rozwoju tej dziedziny ekonomii ${ }^{5}$. Nauka, jaką jest NEI, przywiązuje większą wagę do koordynacji działań wewnątrz firmy oraz jej interakcji z otoczeniem w przeciwieństwie do teorii skupiających się głównie na analizie generowania i alokacji zasobów. Nowa ekonomia instytucjonalna - odchodząc od nierealnych założeń - stawia sobie za cel praktyczne podejście do ekonomii ${ }^{6}$.

Brak odpowiedniej wagi przykładanej do roli, jaką odgrywają w życiu gospodarczym instytucje zarówno formalne, jak i nieformalne, jest wskazywany jako jeden z przyczynków rozwoju NEI ${ }^{7}$. Znaczna część uwagi w podejściu, jakim jest nowa ekonomia instytucjonalna, jest skupiona na instytucjach. Stanowią one gwarancję ciągłości procesów gospodarczych. Ponadto mają zapewnić ochronę praw własności, jak również stabilną politykę fiskalną i monetarną. Pojęcie instytucji może być zdefiniowane jako zbiór reguł i regulacji stanowiących pewne ograniczenia dla zachowań ludzi. Głównym celem każdej instytucji jest ograniczenie niepewności podczas podejmowania określonych decyzji lub działań. Ponadto jako cel pośredni funkcjonowania instytucji jest również wymieniane zmniejszenie ryzyka i obniżenie kosztów

${ }^{2}$ M. Gorynia, Przedsiębiorstwo w nowej ekonomii instytucjonalnej, „Ekonomista” 1999, nr 6, s. 777-790.

${ }^{3}$ W. Stankiewicz, Ekonomia instytucjonalna - zarys wyktadu, Wydanie III uzupełnione, wersja elektroniczna, Prywatna Wyższa Szkoła Businessu, Administracji i Technik Komputerowych, Warszawa 2012, http://www.pwsbia.edu.pl/ (dostęp 08.05.2013), s. 28.

${ }^{4}$ S. Rudolf, Nowa ekonomia instytucjonalna, „Przedsiębiorstwo Przyszłości - Kwartalnik Wyższej Szkoły Zarządzania i Prawa im. Heleny Chodkowskiej” [Warszawa] 2010, nr 1 (2), s. 9-21.

${ }^{5}$ B. Fiedor, Nowa Ekonomia Instytucjonalna jako podstawa teoretycznej refleksji nad procesem transformacji od gospodarki centralnie sterowanej do rynkowej, WIEDZAinfo.pl - Otwarty Uniwersytet Ekonomiczny, http://www.wiedzainfo.pl/ (dostęp 10.05.2013).

${ }^{6}$ S. Rudolf, Nowa ekonomia instytucjonalna..., s. 9-21.

${ }^{7}$ B. Fiedor, Nowa Ekonomia Instytucjonalna... 
funkcjonowania. Wzrost zainteresowania instytucjami ma związek przede wszystkim z generowaniem przez nie kosztów transakcyjnych ${ }^{8}$.

Nowa ekonomia instytucjonalna bazuje na założeniu, że główną rolę we wzroście gospodarczym odgrywają nie innowacje techniczne, ale innowacje organizacyjne, przejawiające się w strukturze instytucjonalnej i możliwości szybkiej adaptacji do zachodzących zmian. Wcześniej innowacje organizacyjne pozostawały w cieniu innowacji technicznych ${ }^{9}$.

Warto zwrócić również uwagę na fakt, że NEI nie odrzuca wszelkich założeń ekonomii neoklasycznej. Stosuje natomiast pewne modyfikacje w zakresie tej teorii. Pozwala to na stopniowe dostosowanie elementów nowej ekonomii instytucjonalnej do ekonomii głównego nurtu. Omawiana poniżej teoria kosztów transakcyjnych $\mathrm{w}$ podstawowych założeniach jest również zgodna $\mathrm{z}$ ekonomią głównego nurtu - stanowiąc w pewnym sensie nie jej przeciwstawność, lecz uzupełnienie $^{10}$.

W teorii ekonomii klasycznej zakłada się racjonalność działań podejmowanych przez jednostkę na podstawie doskonałej informacji. Ograniczenie stanowią jedynie zasoby rzeczowe lub gotówkowe. W przedsiębiorstwie występują tylko koszty produkcji. Nie są uwzględnione interesy różnych grup związanych z funkcjonowaniem firmy, np. samorządów lokalnych, dostawców bądź odbiorców. Oznacza to, iż firma jest traktowana jako tzw. czarna skrzynka. Teoria, jaką jest NEI, zakłada natomiast ograniczoność informacji. Zakres informacyjny może być oczywiście poszerzony, jednak wymaga to poniesienia określonych kosztów transakcyjnych. Nowa ekonomia instytucjonalna zakłada również występowanie w przedsiębiorstwie działania, jakim jest oportunizm rozumiany jako przebiegłe dążenie do realizacji własnych interesów. Zakłada, że takie działanie powinno być eliminowanie $\mathrm{z}$ organizacji. Jest to możliwe dzięki wprowadzeniu odpowiednich regulacji, które będą zniechęcały do tego typu poczynań. Wprowadzenie owych regulacji niesie ze sobą oczywiście także pewne koszty transakcyjne. Warto je jednak ponieść, gdyż doprowadzi to do lepszej i bardziej wydajnej działalności organizacji. Nowa ekonomia instytucjonalna nie odrzuca przy tym założenia o racjonalności działań. Przybliża je nieco do rzeczywistości gospodarczej zakładając, że ograniczona racjonalność polega na tym, iż decydenci organizacyjni są w stanie ustalić, jakie koszty transakcyjne należy ponieść, aby uzyskać określoną informację ${ }^{11}$.

\footnotetext{
${ }^{8}$ S. Rudolf, Nowa ekonomia instytucjonalna..., s. 9-21.

${ }^{9}$ Ibidem, s. 9-21.

${ }^{10}$ M. Gorynia, Przedsiębiorstwo w nowej ekonomii instytucjonalnej..., s. 777-790.

${ }^{11}$ S. Rudolf, Nowa ekonomia instytucjonalna..., s. 9-21.
} 


\section{Teoria kosztów transakcyjnych}

Historia w zakresie teorii kosztów transakcyjnych (TKT) stanowi w teorii ekonomii obszar, w którym wciąż pozostaje wiele do zbadania, chociaż podwaliny pod tę teorię dał już w starożytności Arystoteles zwracając uwagę na występowanie tzw. kosztów wymiany dóbr ${ }^{12}$.

Pojęcie kosztów transakcyjnych wprowadził do ekonomii R. Coase. Zwrócił on uwagę na to, że rynki i firmy stanowią alternatywne sposoby organizacji gospodarczej. W odpowiedniej koordynacji działań gospodarczych poza rynkiem biorą udział również przedsiębiorstwa ${ }^{13}$. Istota firmy polega na stosunkach wymiennych odbywających się w ramach życia gospodarczego, gdyż ceny stanowiące istotę mechanizmu rynkowego generują określone koszty transakcyjne ${ }^{14}$. Stąd często koszty transakcyjne są określane jako „koszty korzystania z mechanizmu cenowego" ${ }^{\text {"15 }}$. Teoria kosztów transakcyjnych przyjmuje transakcje jako podstawową jednostkę analizy. W nowej ekonomii instytucjonalnej przez transakcje może być rozumiany wszelki rodzaj relacji zachodzący pomiędzy jednostkami ${ }^{16}$. Warto również zwrócić w tym miejscu uwagę na fakt, że za przyjęciem transakcji jako podstawowej jednostki analizy przemawia występowanie różnych firm i producentów. Producenci ci mogą stosować odmienne technologie produkcji. Ponadto mogą zawierać ze sobą różnego rodzaju transakcje, w wyniku których powstanie całościowy produkt finalny ${ }^{17}$. Warto też podkreślić, że TKT jest często uznawana za najważniejszy nurt nowej ekonomii instytucjonalnej, stanowiący jej główny trzon ${ }^{18}$.

W interesujący, i wydaje się bardzo praktyczny, sposób koszty transakcyjne zdefiniował K.J. Arrow. Uznał on, iż są to koszty działania systemu gospodarczego ${ }^{19}$. Koszty transakcyjne mogą być również rozumiane jako trzy zależne od siebie elementy, tj. koszty wymiany, koszty pomiaru i koszty zarządzania ${ }^{20}$. Warunkiem występowania kosztów transakcyjnych jest pojawienie się wspomnianych wcześniej oportunizmu oraz ograniczonej racjonalności. Zakres sposobów przeprowadzania transakcji zawiera się pomiędzy rynkiem a przed-

${ }^{12}$ Ł. Hardt, Ekonomia kosztów transakcyjnych - geneza i kierunki rozwoju, Wyd. UW, Warszawa 2009, s. 26, 47.

${ }^{13}$ S. Rudolf, Nowa ekonomia instytucjonalna..., s. 9-21.

${ }^{14}$ M. Gorynia, Przedsiębiorstwo w nowej ekonomii instytucjonalnej..., s. 777-790.

${ }^{15}$ B. Fiedor, Nowa Ekonomia Instytucjonalna...

${ }^{16}$ I. Sobańska, Zmiany $w$ rachunkowości zarzadczej w kontekście teorii kosztów transakcyjnych, „Acta Universitatis Lodziensis” 2011, Folia Oeconomica 249, s. 35-46.

${ }^{17}$ S. Rudolf, Nowa ekonomia instytucjonalna..., s. 9-21.

${ }^{18}$ M. Gorynia, Przedsiębiorstwo w nowej ekonomii instytucjonalnej..., s. 777-790.

${ }^{19}$ K.J. Arrow, The Organization of Economic Activity: Issues Pertinent to the Choice of Market versus Non-market Allocation, [cyt. za:] M. Gorynia, Przedsiębiorstwo w nowej ekonomii instytucjonalnej..., s. 777-790.

${ }^{20}$ I. Sobańska, Zmiany w rachunkowości..., s. 35-46. 
siębiorstwem. Teoria kosztów transakcyjnych uzupełnia wcześniejsze poglądy ekonomiczne w ten sposób, iż wskazuje, że firmy nie są ukierunkowane jedynie na minimalizację kosztów produkcji, a raczej na minimalizację sumy kosztów produkcji i kosztów transakcyjnych $^{21}$.

W ciekawy sposób koszty transakcyjne zdefiniował również Wacław Stankiewicz: „Koszty transakcyjne są częścią łącznych kosztów funkcjonowania systemu społeczno-gospodarczego, która obejmuje nakłady zasobów ponoszone w trakcie zawierania i realizacji wszystkich typów transakcji”22. Koszty transakcyjne można podzielić na sześć podstawowych kategorii23:

- koszty poszukiwania alternatyw - związane z gromadzeniem informacji o potencjalnych cenach i kontrahentach,

- koszty realizacji rozliczeń - wiążące się bezpośrednio z procesem wymiany,

- koszty mierzenia - związane z trudnościami kwantyfikacji w zakresie dóbr i usług,

- koszty zawierania kontraktów - związane z zawieraniem umów określających prawa i obowiązki stron z różnymi kontrahentami,

- koszty specyfikacji i ochrony praw własności - dotyczące nakładów na prawne określenie jednostki dysponującej prawem własności, przedmiotu umowy, zestawu uprawnień oraz warunków i sposobów przekazywania uprawnień między stronami umowy,

- koszty zachowań oportunistycznych - związane z pragnieniem osiągnięcia przez strony własnych celów - często nawet przy rezygnacji z wielu zasad moralnych i społecznych.

W omawianej teorii zostało odrzucone założenie o zerowych kosztach transakcyjnych charakterystyczne dla ekonomii neoklasycznej. Teoria kosztów transakcyjnych zakłada, że tego typu kosztów nie można w pełni wyeliminować. Można je natomiast skutecznie zmniejszać. W teorii tej działania przedsiębiorstwa powinny być rozważane w kontekście szerszym aniżeli ukierunkowane jedynie na podnoszenie konkurencyjności poprzez obniżanie kosztów produkcji. Przedsiębiorstwo będzie w stanie działać na rynku jedynie wtedy, kiedy koszty jego koordynacji będą niższe aniżeli koszty transakcyjne związane z uzyskaniem danych produktów na rynku. Jest to związane z podejmowaniem decyzji typu „kup lub zrób”24. Aktualnie coraz mniej firm uznaje się za samowystarczalne. Stosowanie zasad tzw. szczupłej produkcji oraz budowa odpowiednich relacji z dostawcami mają na celu obniżenie kosztów transakcyjnych i zachowanie

\footnotetext{
${ }^{21}$ M. Gorynia, Przedsiębiorstwo w nowej ekonomii instytucjonalnej..., s. 777-790.

${ }^{22}$ W. Stankiewicz, Ekonomia instytucjonalna-zarys wyktadu..., s. 142.

${ }^{23}$ Ibidem, s. 151-154.

${ }^{24}$ S. Rudolf, Nowa ekonomia instytucjonalna..., s. 9-21.
} 
przez firmy konkurencyjności ${ }^{25}$. Występowanie kosztów transakcyjnych podkreśla interakcje firmy $z$ otoczeniem.

Wspomniana już wcześniej alternatywność sposobów koordynacji działalności gospodarczej prowadzi do tego, że firmy nie mogą rozrastać się w nieskończoność, gdyż koszty koordynacji wzrastają wraz z rozmiarami przedsiębiorstwa. Wzrost firmy może następować do momentu, kiedy poziom kosztów koordynacji przedsiębiorstwa osiągnie poziom identyczny z kosztem działania mechanizmu rynkowego ${ }^{26}$. Warto tu również nadmienić, że alternatywność firm i rynku była poddawana pewnej krytyce. Kwestionowano bowiem założenie, że firmy mogą istnieć bez rynku, a rynek bez firm ${ }^{27}$.

Bezpośrednio $\mathrm{z}$ teorią kosztów transakcyjnych związane jest pojęcie specyficzności aktywów. Polega ono na podziale inicjatyw inwestycyjnych na inwestycje specjalnego przeznaczenia i inwestycje ogólnego przeznaczenia. Dzięki tym pierwszym powstają tzw. specyficzne aktywa, których w razie potrzeby nie można łatwo przemieszczać bez straty ich wartości produkcyjnych. Dokonując inwestycji w tego typu aktywa trzeba wcześniej zastanowić się, czy przewidywana redukcja kosztów znajduje uzasadnienie dla podejmowanego ryzyka i wynikających z tego zagrożeń. Drugi typ inwestycji prowadzi do powstania tzw. aktywów ogólnego przeznaczenia. W przeciwieństwie do aktywów specyficznych można je łatwo przemieszczać bez straty ich wartości produkcyjnych. Oznacza to, że aktywa tego rodzaju mogą być wykorzystywane $\mathrm{w}$ bardzo szeroki sposób dla urzeczywistnienia różnych przedsięwzięć realizowanych przez firmę. Poziom specyficzności aktywów ma znaczący wpływ na podejmowanie wspomnianych już wcześniej decyzji typu „kup lub zrób". Wysoka specyficzność aktywów będzie prowadziła do sytuacji, w której firma będzie produkowała komponenty we własnym zakresie. Jest to związane z wysokim stopniem zależności oraz trudnościami łączącymi się z ciągłymi zmianami adaptacyjnymi wynikłymi z przemian zachodzących na rynku. Niski poziom specyficzności będzie z kolei prowadził raczej do zakupu komponentów aniżeli ich produkcji we własnym zakresie, co jest związane z ograniczonymi możliwościami kontrolowania kosztów produkcji przez organizację wewnętrzną ${ }^{28}$.

Koszty transakcyjne w przedsiębiorstwie mogą być powiązane $\mathrm{z}$ jego hierarchicznym zarządzaniem (tzw. koordynacja pionowa). Można wyróżnić pośród nich m.in. koszty wytwarzania, koszty badań marketingowych, koszty dystrybucji itp. Natomiast koszty transakcyjne sprzężone z działalnością gospodarczą na rynku to np. koszty zawierania kontraktów, koszty poszukiwania partnerów,

\footnotetext{
${ }^{25}$ I. Sobańska, Zmiany w rachunkowości zarządczej..., s. 35-46.

${ }^{26}$ S. Rudolf, Nowa ekonomia instytucjonalna..., s. 9-21.

${ }^{27}$ M. Gorynia, Przedsiębiorstwo w nowej ekonomii instytucjonalnej..., s. 777-790.

${ }^{28}$ S. Rudolf, Nowa ekonomia instytucjonalna..., s. 9-21.
} 
koszty negocjacji, koszty gromadzenia informacji czy też koszty związane $\mathrm{z}$ upadłością dostawcy, ze zmianą ceny ${ }^{29}$.

W przypadku, kiedy mowa o kosztach transakcyjnych wart jest również przywołania podział kosztów transakcyjnych na koszty typu ex post i ex ante zastosowany przez O.E. Williamsona. Do tych pierwszych można zaliczyć koszty stwierdzenia, czy transakcja odbyła się zgodnie z ustalonymi wcześniej warunkami. Wyróżnić tu można koszty utworzenia struktury zarządzania, koszty składowania, koszty monitoringu, koszty rozwiązania ewentualnych sporów, koszty niedostosowań, itp. Do drugich należą natomiast koszty przygotowywania i negocjowania kontraktów oraz różnego rodzaju zabezpieczeń. Zmiany kosztów typu ex ante są uzależnione od rodzaju dóbr i usług, których dotyczy określony kontrakt. Inaczej mówiąc, są to koszty doprowadzenia do transakcji. Należy również zwrócić uwagę na fakt, że oba wymienione rodzaje kosztów, tj. ex post i ex ante, są od siebie współzależne, w związku z czym ich analiza powinna być dokonywana równocześnie ${ }^{30}$.

\section{Praktyczne aspekty teorii kosztów transakcyjnych na rynku ochrony zdrowia}

Dokonując praktycznej analizy w zakresie kosztów transakcyjnych należy zwrócić uwagę na fakt, że empiryczne uchwycenie i weryfikacja teorii kosztów transakcyjnych nie są rzeczą łatwą ${ }^{31}$. Trudności związane z praktycznym ujęciem kosztów transakcyjnych thumaczy się tym, że ekonomiści nie uzgodnili zestawu ich głównych składników, od czego zależy ich ilościowa ocena ${ }^{32}$. Niemniej jednak poniżej zostanie dokonana próba klasyfikacji podstawowych typów kosztów transakcyjnych na rynku ochrony zdrowia w Polsce.

Na polskim rynku ochrony zdrowia można wyróżnić wiele instytucji, które spełniają określone, niekiedy bardzo różnorodne funkcje. Jako przykłady można tu przytoczyć chociażby Ministerstwo Zdrowia - resort zajmujący się ochroną i profilaktyką zdrowotną pacjentów, Narodowy Fundusz Zdrowia - który pełni funkcję narodowego płatnika i ma za zadanie m.in. analizować koszty ochrony zdrowia, aby zapewnić jej jak najlepsze funkcjonowanie oraz działać na rzecz promocji zdrowia ${ }^{33}$ czy też świadczeniodawców. Szczególnie zróżnicowana jest

${ }^{29}$ Ibidem, s. 9-21.

${ }^{30}$ O.E. Williamson, Ekonomiczne instytucje kapitalizmu. Firmy, rynki, relacje kontraktowe, Wyd. Nauk. PWN, Warszawa 1998, s. 390 [cyt. za:] S. Rudolf, Nowa ekonomia instytucjonalna..., s. 9-21; M. Gorynia, Przedsiębiorstwo w nowej ekonomii instytucjonalnej..., s. 777-790.

${ }^{31}$ G. Koenig, Les théories de la firme, Economica, Paris 1993 [cyt. za:] M. Gorynia, Przedsiębiorstwo w nowej ekonomii instytucjonalnej..., s. 777-790.

${ }^{32}$ W. Stankiewicz, Ekonomia instytucjonalna - zarys wyktadu ..., s. 155.

${ }^{33}$ Ustawa o świadczeniach opieki zdrowotnej finansowanych ze środków publicznych z dnia 27 sierpnia 2004, DzU, 2004, nr 210, poz. 2135, art. 97, pkt 3. 
ta ostatnia grupa instytucji. Pośród niej występują podmioty szpitalne, przychodnie ambulatoryjnej opieki specjalistycznej (AOS), przychodnie podstawowej opieki zdrowotnej (POZ), apteki, jak również wiele innych podmiotów.

W ostatnich latach w Polsce w zakresie ochrony zdrowia dało się zauważyć wprowadzenie wielu innowacji organizacyjnych mających na celu przyczynienie się, w ten czy inny sposób, do obniżenia ogólnych kosztów funkcjonowania - w tym również kosztów transakcyjnych - polskiego systemu opieki zdrowotnej. Jako przykłady można by tu wymienić kompleksową reformę służby zdrowia z roku 1999, wprowadzającą do systemu mechanizmy rynkowe, powołanie w 2003 r. do życia Narodowego Funduszu Zdrowia czy wprowadzenie w roku 2011 ustawy o działalności leczniczej.

Powołanie do życia nowych organizacji i wprowadzenie nowych instytucji wiąże się również z występowaniem nowych rodzajów kosztów transakcyjnych w systemie. Na podstawie wcześniejszych rozważań na rynku ochrony zdrowia można wyróżnić wiele ich rodzajów. Poniżej zostaną zaprezentowane różne rodzaje kosztów transakcyjnych występujących na rynku ochrony zdrowia w Polsce. Mając na uwadze fakt, że koszty tego typu - pomimo braku możliwości ich pełnej eliminacji - można skutecznie zmniejszać, zostały tu również omówione sposoby ewentualnej redukcji tych kosztów.

Zgodnie z definicyjnym ujęciem kosztów transakcyjnych jako kosztów działania systemu gospodarczego należy zastanowić się, jaka jest idea funkcjonowania systemu opieki zdrowotnej w Polsce. Wiąże się to również w pewien sposób z rozgraniczeniem kosztów produkcyjnych, jak i kosztów transakcyjnych. Wydaje się, iż koszty związane stricte $\mathrm{z}$ zapewnieniem obywatelom odpowiedniego poziomu opieki zdrowotnej i udzielaniem świadczeń zdrowotnych przez podmioty lecznicze mogą być traktowane jako koszty produkcyjne. Natomiast pozostałe koszty, tj. wydatki związane $\mathrm{z}$ działaniem i obsługą systemu opieki zdrowotnej, mogą stanowić tu koszty transakcyjne.

$\mathrm{Na}$ gruncie przywoływanego wcześniej podziału kosztów transakcyjnych jako przykład kosztów poszukiwania alternatyw można wymienić poszukiwanie przez płatnika najlepszego świadczeniodawcy. Odbywa się to na zasadzie organizowanego cyklicznie konkursu ofert. Forma konkursu ma zapewne doprowadzić do obniżenia kosztów transakcyjnych związanych z poszukiwaniem najlepszych alternatyw. Poszczególni świadczeniodawcy składają swoje oferty, które następnie są analizowane przez płatnika, jakim jest NFZ, pod kątem określonych kryteriów. Spośród ofert wybierane są te najlepsze i właśnie z tymi placówkami odbywa się kontraktowanie świadczeń. Inny przykład kosztów transakcyjnych na gruncie tego podziału mogą stanowić koszty specyfikacji i ochrony praw własności. Tutaj można wyróżnić nakłady związane z produkcją rożnego rodzaju leków i specyfików medycznych przez koncerny farmaceutyczne. Dla obniżenia tego typu kosztów transakcyjnych kluczowe znaczenie może mieć funkcjonowanie takiej instytucji, jak np. urząd patentowy. Można tu 
przywołać również koszty związane z odpowiednią wyceną świadczeń zdrowotnych na podstawie ich specyfikacji. Aktualnie zajmuje się tym NFZ. Planowane jest jednak powołanie specjalnej Agencji Taryfikacji, która ma czuwać nad właściwym zawieraniem umów i ich wyceną zgodną ze specyfikacją świadczeń $^{34}$. Kolejną z kategorii, którą można dostrzec na rynku ochrony zdrowia, są koszty zawierania kontraktów. Dotyczy to zwłaszcza kontraktowania świadczeniodawców z Narodowym Funduszem Zdrowia. Świadczeniodawcy muszą spełnić ściśle określone przez płatnika warunki. Ponadto muszą ponieść pewne koszty związane z zakupem odpowiedniego oprogramowania, które umożliwi udział we wspomnianym już wcześniej konkursie ofert.

Analizując funkcjonowanie polskiego rynku opieki zdrowotnej w kontekście teorii kosztów transakcyjnych nie sposób nie wspomnieć w tym miejscu o pojęciu specyficzności aktywów. Specyficzność aktywów jest zauważalna przede wszystkim po stronie świadczeniodawców. Często przygotowując się do działalności medycznej muszą oni dokonać określonych inwestycji związanych z przystosowaniem swoich placówek do świadczenia usług medycznych określonego typu. Inwestycje te mogą mieć charakter zarówno inwestycji ogólnego, jak i szczególnego przeznaczenia. Do tych pierwszych, wskutek których powstają aktywa niespecyficzne, można zaliczyć np. budowę budynku poradni czy zatrudnienie personelu administracyjnego. Do tych drugich - dzięki którym powstaną aktywa specyficzne - można zaliczyć zakup specjalistycznego sprzętu medycznego w ramach określonej poradni AOS lub też zatrudnienie lekarzy specjalistów. Warto w tym miejscu zaznaczyć, że lekarze na ogół nie stanowią aktywów specyficznych, z zastrzeżeniem, że mogą stanowić takie aktywa, jeśli są wykształceni $\mathrm{w}$ ramach unikatowej specjalności ${ }^{35} . \mathrm{Z}$ takim przypadkiem mamy do czynienia właśnie $w$ tej sytuacji. Podkreślać ten fakt mogą zwłaszcza liczne przypadki braków w kadrze lekarzy specjalistów ${ }^{36}$.

Istnieje wiele problemów związanych $\mathrm{z}$ występowaniem aktywów specyficznych na rynku ochrony zdrowia. Dla przykładu można tu omówić wspomniane inwestycje $\mathrm{w}$ poradnie specjalistyczne łączące się z zakupem odpowiedniego sprzętu wymaganego przez NFZ i z zatrudnieniem odpowiedniej kadry specjalistycznej. Jak już było wcześniej wspomniane, NFZ zawiera ze świadczeniodawcami cykliczne kontrakty na świadczenie usług medycznych. Problem związany z dużą specyficznością aktywów może pojawić się w momencie, kiedy Fundusz zdecyduje się nie przedłużać kontraktu na określony rodzaj ambulatoryjnej opieki specjalistycznej. Fundusz może zmienić również warunki kontraktu. Takie przypadki się zdarzają - zwykle dotyczą jednak nieuczciwych świad-

${ }^{34}$ J. Janik, Koszty procedur wyceni Agencja Taryfikacji, ale tylko z tego powodu pieniędzy nie przybędzie..., Portal Rynek Zdrowia, http://www.rynekzdrowia.pl/ (dostęp 05.05.2013).

${ }^{35}$ S. Rudolf, Nowa ekonomia instytucjonalna..., s. 9-21.

${ }^{36}$ A. Katrynicz, Specjalista potrzebny od zaraz, „Gazeta Lekarska”, 10.2008, s. 6-7. 
czeniodawców $^{37}$. Świadczeniodawca, z którym narodowy płatnik nie podpisał umowy, może zacząć poszukiwać dla swojej placówki nowego rynku zbytu, np. pośród pacjentów komercyjnych lub jako podwykonawca jednej z firm oferujących usługi abonamentowe - wiąże się to jednak często ze znacznymi kosztami transakcyjnymi. W przytoczonym przykładzie można zauważyć występowanie kolejno kosztów transakcyjnych związanych z upadłością dostawcy (tutaj raczej z brakiem kontraktowania przez NFZ - co może być jednak w pewien sposób nawiązaniem do kosztów tego typu), kosztów zawierania nowych kontraktów, poszukiwania nowych partnerów, gromadzenia informacji czy kosztów negocjacji i gromadzenia informacji - czyli z typami kosztów transakcyjnych powiązanych z działalnością gospodarczą na rynku.

$\mathrm{W}$ przypadku ostatniego $\mathrm{z}$ wymienionych $\mathrm{w}$ niniejszym opracowaniu podziału kosztów transakcyjnych, tj. na koszty typu ex post i ex ante, również można przywołać kilka praktycznych przykładów występujących w sektorze ochrony zdrowia. Sam akt transakcji będzie tu polegał na udzielaniu pacjentom świadczeń zdrowotnych.

Jak to było już wcześniej zaznaczone, do kosztów typu ex post zalicza się m.in. koszty utworzenia struktury zarządzania i monitoringu. I tak dla przykładu można tu wymienić utworzenie w ramach danego świadczeniodawcy odpowiedniej struktury zarządzania dla placówek podstawowej opieki zdrowotnej, ambulatoryjnej opieki specjalistycznej lub lecznictwa szpitalnego. Owa struktura zarządzania może się przejawiać w odpowiednio przygotowanych strukturach administracyjnych. Koszty monitoringu mogą się w tym przypadku łączyć $\mathrm{z}$ analizami związanymi $\mathrm{z}$ dynamiką wzrostu liczby pacjentów określonej poradni czy ogólnie z przygotowaniem odpowiednich zestawień na potrzeby rozliczeń z płatnikiem. Pośród innych kosztów typu ex post można wyróżnić koszty składowania, koszty rozwiązania ewentualnych sporów i koszty niedostosowań. Te pierwsze mogą się np. wiązać z koniecznością utrzymywania odpowiedniego poziomu zapasów różnego rodzaju materiałów medycznych (np. bandaże, strzykawki, ręczniki papierowe), niezbędnych do udzielania codziennych świadczeń. Ponadto mogą mieć związek z potrzebą utrzymania odpowiedniej infrastruktury w postaci specjalistycznego sprzętu medycznego, a także wyposażenia biurowego. Koszty rozwiązania ewentualnych sporów mogą się wiązać bezpośrednio z uchybieniami wykazywanymi świadczeniodawcy przez płatnika. Będą one skutkowały brakiem uzyskania finansowania za udzielone świadczenia lub ewentualnymi karami nałożonymi przez płatnika. Uchybienia mogą polegać np. na błędnym kwalifikowaniu i rozliczaniu świadczeń, na niezgodności informacji zawartych $\mathrm{w}$ raportach statystyczno-medycznych

${ }^{37}$ Serwis internetowy magazynu Wprost, Szpitale bez umów. NFZ: pacjenci nie straca dostępu do leczenia, http://www.wprost.pl/ (dostęp 22.02.2013). 
$\mathrm{z}$ dokumentacją medyczną, braku w dokumentacji medycznej potwierdzenia wykonania świadczeń, nieprawidłowym prowadzeniu dokumentacji medycznej, brakach w wymaganym sprzęcie, braku wymaganych kwalifikacji personelu czy braku aktualizacji zasobów sprzętowych i personelu ${ }^{38}$. Do kosztów niedostosowań można natomiast zaliczyć wydatki ponoszone przez daną jednostkę związane z brakiem odpowiedniej liczby stałych pracowników medycznych do obsługi danej poradni - w szczególności lekarzy specjalistów, których nieobecności aktualnie są mocno odczuwalne. Takie niedostosowania prowadzą często do konieczności poszukiwania pracowników, którzy podejmą się pracy niejednokrotnie dodatkowo, w ramach umów cywilno-prawnych. Warto w tym miejscu również nadmienić, że decyzja odnośnie do pozyskania dodatkowych pracowników może być równie często wspomnianym rodzajem decyzji typu „kup lub zrób". Mechanizm rynkowy często jest w stanie zaoferować pracę lekarzy specjalistów na korzystniejszych warunkach aniżeli wtedy, gdyby wchodzili oni w strukturę hierarchiczną firm na zasadzie pracowników etatowych.

Do kosztów typu ex ante zaliczyć można natomiast koszty zabezpieczeń oraz koszty przygotowania i negocjowania kontraktów. Jeśli chodzi o koszty zabezpieczeń, to mogą one wiązać się np. z ubezpieczeniem działalności na wypadek braku wywiązania się z kontraktów. Do takich ubezpieczeń w sektorze opieki zdrowotnej można zaliczyć np. ubezpieczenia odpowiedzialności cywilnej lekarzy i lekarzy dentystów czy wprowadzone przez ustawę o działalności leczniczej ubezpieczenie $\mathrm{z}$ tytułu zdarzeń medycznych. W ramach kosztów przygotowania kontraktów można wyróżnić wspomniane już wcześniej w opracowaniu koszty związane z zawarciem kontraktu z NFZ, tj. chociażby na zakup oprogramowania do udziału w konkursie ofert itp. Do kosztów negocjowania można zaliczyć chociażby koszty ewentualnego odwołania od decyzji płatnika w sprawie nieprzyznania kontraktu, przyznania kontraktu zbyt małego lub tzw. nadwykonań.

Należy również pamiętać, że koszty typu ex post i ex ante mają charakter współzależny i wymienione przykładowo koszty rozwiązania ewentualnych sporów na rynku medycznym mogą wiązać się bezpośrednio z kosztami negocjacji.

Odpowiednie oszacowanie bądź kalkulacja kosztów transakcyjnych wydaje się bardzo ważnym zadaniem z punktu widzenia każdego podmiotu funkcjonującego w życiu gospodarczym. Może przyczynić się do określenia optymalnych rozmiarów działalności firmy i tym samym do jej lepszego funkcjonowania. Szczególnie istotne jest to zwłaszcza na rynku ochrony zdrowia, który stanowi w przypadku społeczeństwa bardzo wrażliwy obszar.

38 Sprawozdanie z działalności Narodowego Funduszu Zdrowia za 2011 rok, Narodowy Fundusz Zdrowia, Warszawa 2012, s. 89. 


\section{Zakończenie}

Przedsiębiorstwa działające na szeroko rozumianym rynku ochrony zdrowia ponoszą szereg różnych kosztów transakcyjnych. W niniejszym opracowaniu została podjęta próba identyfikacji niektórych spośród tychże kosztów. Przytoczone koszty stanowią niewątpliwie bardzo ważny element funkcjonowania przedsiębiorstw jako składowa sumy ogólnych kosztów - obok kosztów produkcji. Zarówno analizując działalność przedsiębiorstwa na rynku medycznym, jak i rozważając wejście na ten rynek przedsiębiorca powinien zwrócić uwagę na istnienie koszów transakcyjnych. Utrzymywanie ich na odpowiednim poziomie oraz ewentualna minimalizacja stanowią bowiem warunek właściwego funkcjonowania firmy.

Wykorzystanie i uwzględnienie w różnego rodzaju analizach kosztów transakcyjnych może mieć kluczowe znaczenie w przypadku polskiego sektora ochrony zdrowia, który pozostaje w stanie permanentnego niedofinansowania.

Opracowanie oczywiście nie wyczerpuje w pełni tematu związanego $\mathrm{z}$ funkcjonowaniem systemu opieki zdrowotnej w kontekście teorii kosztów transakcyjnych. Zwraca jednak uwagę na pewne praktyczne możliwości wykorzystania założeń tej teorii w omawianym obszarze. Otwiera również pole do dyskusji w zakresie praktycznego zastosowania TKT na rynku opieki zdrowotnej i ma na celu zachęcenie do dalszych badań i analiz w tej dziedzinie. Wykorzystanie założeń TKT, jako uzupełnienie dla ekonomii głównego nurtu, może przyczynić się do poprawy funkcjonowania podmiotów w realiach gospodarczych - w tym również na szeroko pojętym rynku medycznym.

\section{Literatura}

Fiedor B., Nowa Ekonomia Instytucjonalna jako podstawa teoretycznej refleksji nad procesem transformacji od gospodarki centralnie sterowanej do rynkowej, WIEDZAinfo.pl - Otwarty Uniwersytet Ekonomiczny, http://www.wiedzainfo.pl/ (dostęp 10.05.2013).

Gorynia M., Przedsiębiorstwo w nowej ekonomii instytucjonalnej, „Ekonomista” 1999, nr 6.

Hardt Ł., Ekonomia kosztów transakcyjnych - geneza i kierunki rozwoju, Wyd. UW, Warszawa 2009.

Janik J., Koszty procedur wyceni Agencja Taryfikacji, ale tylko z tego powodu pieniędzy nie przybędzie..., Portal Rynek Zdrowia, http://www.rynekzdrowia.pl/ (dostęp 05.05.2013).

Katrynicz A., Specjalista potrzebny od zaraz, „Gazeta Lekarska”, 10. 2008.

Rudolf S., Nowa ekonomia instytucjonalna, „Przedsiębiorstwo Przyszłości - Kwartalnik Wyższej Szkoły Zarządzania i Prawa im. Heleny Chodkowskiej” [Warszawa] 2010, nr 1 (2).

Serwis internetowy magazynu Wprost, Szpitale bez umów. NFZ: pacjenci nie straca dostępu do leczenia, http://www.wprost.pl/ (dostęp 22.02.2013).

Sobańska I., Zmiany w rachunkowości zarządczej w kontekście teorii kosztów transakcyjnych, „Acta Universitatis Lodziensis” 2011, Folia Oeconomica 249. 
Sprawozdanie z działalności Narodowego Funduszu Zdrowia za 2011 rok, Narodowy Fundusz Zdrowia, Warszawa 2012.

Stankiewicz W., Ekonomia instytucjonalna - zarys wykladu, Wydanie III uzupełnione, wersja elektroniczna, Prywatna Wyższa Szkoła Businessu, Administracji i Technik Komputerowych, Warszawa 2012, http://www.pwsbia.edu.pl/ (dostęp 08.05.2013).

Ustawa o świadczeniach opieki zdrowotnej finansowanych ze środków publicznych z dnia 27 sierpnia 2004, DzU, 2004, nr 210, poz. 2135, art. 97, pkt 3.

\section{Streszczenie}

Teoria kosztów transakcyjnych stanowi relatywnie nowe podejście mające na celu objaśnienie zasad funkcjonowania przedsiębiorstwa. Wpisuje się ona w nurt nowej ekonomii instytucjonalnej. Stanowi uzupełnienie założeń ekonomii głównego nurtu uwzględniające istotną rolę kosztów transakcyjnych - poprzez co kładzie nacisk na interakcje firmy $\mathrm{z}$ otoczeniem. W niniejszym opracowaniu została podjęta próba odniesienia pewnych aspektów tej teorii do praktyki gospodarczej, a konkretnie do rynku ochrony zdrowia.

\section{Summary}

\section{COMPANIES OPERATING IN POLISH HEALTHCARE SYSTEM IN THE CONTEXT OF TRANSACTION COST THEORY}

Transaction cost theory is still portrayed as a relatively new approach in economy aimed at explaining rules and principles of running a company. It consists a part of a wider attitude represented by new institutional economics and is focused on company's interactions with the environment. In this paper there was made an attempt to reference certain aspects of this theory to business practice - especially to the companies operating in Polish healthcare system.

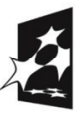

\section{KAPITAt LUDZKI}

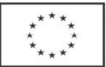

Projekt „Doktoranci - Regionalna Inwestycja w Młodych naukowców społeczno-humanistycznych - Akronim D-RIM SH" jest wspólfinansowany przez Unię Europejska ze środków Europejskiego Funduszu Społecznego w ramach Programu Operacyjnego Kapitał Ludzki, Poddziałanie 8.2.1. 